\title{
Territorial Presence as a Ground for Claims: Some Reflections
}

\author{
Linda Bosniak
}

Rutgers University, bosniak@law.rutgers.edu

DOI: http://dx.doi.org/10.5324/eip.v14i2.3490

(cc) BY

This is an open access article distributed under the terms of the Creative Commons Attribution 4.0 International License, which permits unrestricted use, distribution, and reproduction in any medium, provided the original author and source are credited.

"Territorial Presence as a Ground for Claims: Some Reflections" returns to political theory to assess the moral and legal position of those individuals who reside within the territory of liberal democratic states, but whose presence is unauthorized by the state. The author poses the question as to what their physical presence means and does from a political perspective. The paper is part of a broader political phenomenology of territoriality in liberal national thought, one that emphasizes the idea that migrants' physical presence within the state's territory lies at the analytical heart of the conversation about irregular immigrants. What is paradoxical about territorial presence of unauthorized migrants is that such presence is simultaneously (1) the source of the offence that states invoke as a justification for rendering them 'illegal'; (2) the basis for basic fair treatment protections the migrants may claim from the state while present; and (3) the ground for claims they make (or that are made on their behalf) to remain present - i.e., to stay in the territory. The phenomenology of territorial presence is thus fertile ground for analyzing arbitrary and repressive law-making in migration, as well as for theorizing "immigrant justice" as resistance to such law-making.

In the course of this discussion, the author analyzes the widely invoked idea of "sanctuary" as a conceptual frame for such resistance. She concludes that "sanctuary" claims, as propounded by both liberal humanitarians and immigrant justice advocates, seek to ground rights and recognition in what is claimed to be the overriding ethical significance of immigrants' territorial presence now - of their already-hereness. The author shows how deployments of "sanctuary" strategies offer a powerful logic of safe harbor for those already-here, one that is ever more necessary in a period of increasingly repressive internalized borders. Nevertheless, she also concludes, sanctuary-as-strategy falls theoretically short of taking on the constitutive border exclusionism that gives rise to the predicament of irregularity in the first instance. A more robust critical stance would have to insist that borders not just be mitigated, but radically deconstructed and even abolished. It is at precisely this abolitionist juncture, however, that critical theory faces the constraints of feasibility which action-oriented policy reformers demand. The author regards grappling with the utility/utopia dilemma to be a vital task confronting critical legal and political theorists engaged in rethinking arbitrary and repressive law-making, especially in view of the rampant new inequalities produced by a global political order grounded in sovereign borders. 
Keywords: borders, territorial presence, irregular status, United States, resistance

My subject today is the complex posture of persons who are located inside the territory of self-avowed liberal democratic states when their presence in the territory has been deemed by that state to be unauthorized. What does the fact of their physical presence mean and do politically? The paper is part of a broader political phenomenology of territoriality in liberal national thought.

Let us start with this definitional point. The very existence of a class of people designated as irregular migrants within state polities presupposes three things. First, it presupposes that such polities maintain formal exclusionary border regimes and that in such regimes, some persons are predesignated as ineligible for entry. Second, it presupposes that those exclusion rules do not, in fact, function to fully preclude entry and presence of such persons. This may be by virtue of state incapacity or state hypocrisy, or both. Finally, it presupposes that these polities do not treat the mere physical arrival of a person into the territory as an automatic basis for full membership in the polity. Taken together, this means that irregular immigrants are territorially present in a state that purports to eschew their presence and that they inhabit a space that maintains stratified and restricted membership rules.

Notice that in this particular inside-outness scenario, it is precisely the person's physical presence within the territory that is designated by the state as an offense or a wrong - against the state itself (Bosniak 2016). In turn, this offense is invoked to justify both the person's possible forcible removal from the territory and, short of that, the imposition of disadvantageous and repressive treatment during the time as the person remains territorially present. Stated another way, the territorial presence of immigrants in contravention of the state's formal immigration regulations is illegalized, and that illegalized presence is invoked to justify both their removal from, and legal subjection within, the territory.

Nevertheless, in broadly liberal democratic states, the territorial presence of illegalized migrants not only provides the basis for legal subjugation. These people's physical presence in the territory is also precisely what serves to ground claims, made both by migrants themselves and on their behalf by others for protective treatment at the hands of the state. These presence-based protective claims arise in two distinct (though often overlapping) settings.

First, protective claims based on presence are raised to champion immigrants' basic treatment under general law. In democratic states, persons within the territorial jurisdiction of the state are theoretically due basic legal protections qua persons; such protections include due process of law, access to schooling for children, and juridical recognition as legal subjects. This territorial personhood norm undergirds the law of most liberal states today (Bosniak 2010). For the liberal state, a person's presence "on its soil" generally occasions state responsibility as a matter of law, imposing minimum standards on that person's treatment. ${ }^{1}$

Indeed, it is precisely the desire to avoid incurring the formal obligations attending a person's territorial presence which motivates states to make drastic efforts to prevent noncitizen individuals from arriving into their territory at all. It 
is also why migration-receiving states employ various convoluted legal fictions, including formal territorial excision (e.g., Weston Phippin 2016), and deploy various offshoring detention mechanisms to render people who would otherwise qualify as being physically inside the territory as not on the soil, thereby deeming them to be not "present" for legal purposes. The goal is to evade, by any means possible, the responsibilities of the state triggered by a person's territorial insideness.

Note that these rights attending territorially present persons exist notwithstanding that person's status under, and subjection to, the same state's immigration laws (Bosniak 2007). To be sure, the fact that territorially present noncitizens are also subject to immigration regulatory action inside state territory functions, in various ways, to curtail the potential and actualization of basic personhood rights. Still, it remains the case that rights of territorially-present persons are embedded in liberal law and at times can be deployed to circumscribe state immigration enforcement power and protect irregular immigrants.

Second, it is precisely irregularized migrants' territorial presence over a span of time which becomes the basis for their claims for protection against deportation or removal from the territory. Territorial, that is, presence serves as the ground for their claims for the right to stay. Regularization claims, whether they take the discursive form of legalization, amnesty, asylum or some other mechanism, always presuppose and pertain to a population that is already-present. Indeed, migrants and their advocates specifically invoke that already-hereness as the foundation of the claim. ${ }^{2}$

At the outset, therefore, we can see that it is migrants' physical presence within the state's territory that lies at the analytical heart of the conversation about irregular immigrants. Their territorial presence is simultaneously the source of the offense that states invoke as a justification for illegalizing them, the basis for protections the migrants may claim against the state for basic fair treatment while present, and the ground for claims they make (or that are made on their behalf) to remain present - i.e., to stay in the territory.

About this core significance of physical presence in territory, there is much to discuss. If I had been speaking with you a few months ago, before the recent election in my country, I would have further analyzed some of the political and legal paradoxes posed by territorialist ethics in a (neo)liberal nationalist moment. But it has been a momentous year - in the world, and in the United States. Some of the paradoxical tensions of liberalism within national polities have begun to mutate and even collapse in this increasingly illiberal moment. I write in political theory but I am also a U.S. legal scholar, and I speak from both of those positions. Furthermore, I cannot help but intervene as a distressed citizen - first of all, as a citizen of a country whose government is savagely undercutting many of the premises of liberal constitutionalism, but also as a citizen of this particular historical moment and moreover - as a citizen of a transnational community of people who are engaged in a project of seeking justice for migrants and immigrants, among others.

My plan, therefore, is the following. I first analyze some recent legal developments pertaining to the governance of irregular noncitizen immigrants in the United States. Although this focus is nationally specific, the observations have relevance for, and analogies with, developments in other liberal or formerly liberal states. This section of the paper is diagnostic. Thereafter, I will consider questions 
about how these developments bear on the project of theorizing "immigrant justice". Here, I reflect on the current moment of evolving resistance to growing illiberalization in domestic politics. In the U.S. and sometimes elsewhere, this has increasingly taken the form and designation of a politics of "sanctuary". I will consider the meaning of the concept of sanctuary in this setting and ask how the idea of sanctuary relates to the kinds of claims that both liberal humanitarians and immigrant justice advocates have been making over the last few years. These are claims that - not incidentally - ground protection in what exponents cite as the overriding ethical significance of immigrants' territorial presence - their alreadyhereness - as the basis for recognition and rights.

\section{Border Pervasion in the United States}

As is now well-known, assaults on the liberal democratic order in the United States - on constitutionalism, on civility, on truth - have ranged almost indiscriminately across domains since the 2016 election. Even so, immigration stands out. From early in the campaign, it was Trump's showcase issue, and it remains one of the foremost arenas in which the new America-First, nativist shock politics are being enacted. A number of different initiatives have been pursued.

The campaign against immigrants began with repeated incantations about the Wall - a wall to be built, it was declared, along the 2,000 mile length of the United States - Mexico border. ${ }^{3}$ This was quickly followed by attempted implementation of the Ban - a ban on admitting people from several Muslim majority nations (although when faced with judicial challenges, the Administration has attempted to disavow that the law is religiously or racially motivated, and included non-Muslim majority states in the roster of banned nationalities). ${ }^{4}$

But there has been a third leg on the Trumpian nativist stool, ${ }^{5}$ and it involves an amplified surge in the interior enforcement of the immigration laws. According to the government, the targets of such interior enforcement are - as they have long been - "illegal aliens", as well as "criminal aliens" and "alien terrorists", but now novel discursive Trumpian elements have been added to the mix, including specific invective against "bad hombres", against "extended family chain migrants" and, most vividly, against immigrants coming from "shithole countries" (Dawsey 2018). One way to conceptualize this escalation in interior enforcement is as an attempted Purge, fundamentally on racial grounds. In contrast to the Wall and the Ban, which are meant to enact barriers against the ingress of undesirable foreigners, this campaign of heightened interior enforcement displays a commitment to evacuate foreigners already inside, with a now-unalloyed focus on those foreigners who are racially marked or deemed to be undesirable. Note, moreover, that the significance of this campaign of internalized border pervasion goes well beyond a wished-for ejection of such persons: it also functions as a mode of highly repressive and subordinating governance of noncitizens inside the national territory.

Before describing the nature of this governance, I hasten to emphasize that there is nothing new, per se, in the enforcement of the border in the interior via mechanisms of immigration control. Indeed, internalized enforcement of borders, including arrests, detentions and deportations, are part of the longstanding reality of various modes of relatively liberal governance regimes (Bosniak 2006). Nor can we forget that President Obama earned - not unfairly - the moniker of Deporter- 
in-Chief during his eight-year tenure. And to be clear: Obama was not a liberal outlier. Liberal activists and liberal theorists have generally accepted the legitimacy of deportation in principle as long as it's done selectively, with due process and some degree of humanitarian discretion (Bosniak 2016). Getting tough on immigrants convicted of crimes and those suspected of terrorism (each of these themselves racial projects, e.g., Volpp 2002; Armenta 2017) has consistently been conceded by liberals as the cost necessary to pursue more generous policies for assertedly more deserving immigrants.

Still, the landscape is shifting tectonically under the new Administration. Selectivity, due process, and humanitarian discretion have been specifically jettisoned. Instead, law and policy are effecting a thoroughgoing internal pervasion of border enforcement and border norms into more domains, more locations, and more moments of existence. This pervasion begins as a matter of rhetoric but is accomplished materially. It amounts to a turbo-charging, both practical and symbolic, of interior immigration enforcement - through a process that can only be described as ubiquitization of the border.

Border ubiquitization, in turn, transmutes the structure of immigration law and policy as it has existed under United States law for several decades. Specifically, it has already begun to upend a kind of dynamic settlement that has characterized the status of irregular immigrants in the U.S. for decades. As I have shown elsewhere, this settlement has always been contested and precarious, involving constant jurisdictional skirmishes and battles of position at the constitutional, statutory and regulatory levels between norms of sovereign authority and individual right (Bosniak 2006: chapters 3-4). Still, and overall, the regime represented a certain broad accommodative standoff - one in which state enforcement power operated with enormous scope and yet was also sometimes constrained in various ways by, and in light of, recognized protections of individuals.

Before returning to the current ruptural moment, I offer a few words about the basis of this now-threatened liberal nationalist settlement. On the one hand, the border is always treated as legally and politically exceptional in democratic states. Borders are always understood to operate, to some degree, beyond the reach of liberal democratic governance. Indeed, in prevailing liberal democratic thought, borders are commonly regarded as preconditional for the very existence of democracies - as being constitutive of the sovereign space within which liberal democracy is supposed to occur. Therefore, borders themselves are regarded as definitively not the product of democratic norms and practice, and (mostly) not as subject to them, but rather, as somehow constitutively outside and prior (Bosniak 2017).

Nevertheless, there is another side of the equation. Borders enforced in the liberal state's interior have had to co-exist with, and accommodate, certain liberal norms of inclusion and recognition of individuals in ways that sometimes serve to constrain their jurisdiction. As noted above, commitments to liberal legalism, both in the US and in other liberal democratic states, protect certain basic rights of territorially present persons - at least formally: certain core rights of the individual in the civil and social spheres of the polity. It is important not to overstate. Unquestionably, in a regime of drastic economic inequality and racialized stratifications, the invocation of these rights often had more symbolic consequence than concrete effect. Yet it is still the case that the articulated, avowed norms of 
liberalism have protected all territorially present individuals in relation to state power. The upshot is that the internal national space of liberal democratic states has, for decades, been governed by overlapping and often-nonconvergent regulatory regimes: the sovereign border prerogative (let's call it borderism), on the one hand, and a liberal individualist legalism, on the other. The interplay between these regimes - the dynamic map of their respective jurisdictions - is exceedingly byzantine and contested (Bosniak 2006) - and, of course, the way this overlap plays out differs across settings and over time. But commonalities exist across settings: one can identify in each somewhat equilibrated wars of position between borderism and liberal individualism. In this formation, the interior border is sometimes constrained by liberal norms, and meanwhile, liberal norms are sometimes undercut by those border imperatives. In broad form, this is what liberal nationalism - or a nationally framed liberal legalism - has looked like.

And yet, to return to the argument I began making earlier, the current illiberalizing moment is beginning to upend this uneasy settlement. In the United States specifically, the Trump administration has launched a belligerent campaign of interior border enforcement - and is carrying it out to a degree and in ways that threaten to undo constraints on state power that individual rights commitments have until now sometimes provided.

\section{Border Pervasion on the Ground}

Trump's executive order titled Border Security and Immigration Enforcement Improvements, issued five days after his inauguration, begins with this Declaration of Purpose:

Interior enforcement of our Nation's immigration laws is critically important to the national security and public safety of the United States. Many aliens who illegally enter the United States and those who overstay or otherwise violate the terms of their visas present a significant threat to national security and public safety (Border Security and Immigration Enforcement Improvements).

The particular policy initiatives that have flowed from this and other declarations include the following actions.

\section{Widening of the Enforcement Net}

First, the new administration formally eliminated tiered and prioritized protective discretion in immigration enforcement and is now mandating enforcement against any and all suspected immigration law violators. This departs from the policy of the Obama Administration which had expressly deprioritized immigration enforcement against certain irregular immigrants with no criminal record, and had affirmatively declined to enforce immigration law against certain categories of irregularly present noncitizens - sick people, pregnant women, children, military veterans and people pursuing civil rights claims, among others. As noted above, Obama's policy was to instead focus the government's enforcement arsenal on people characterized as "criminal aliens". This focus on criminality was itself problematic - especially given the ever-broadening legislative definition of crimes triggering deportation. Yet the prior policy did leave millions of undocumented 
persons that the government had characterized as "otherwise law-abiding," more or less alone. Moreover, that administration undertook affirmative policies to protect, ex ante and en masse, some classes of irregular migrants - such as through the DACA program.

However, the Trump administration has expressly rescinded these policies of deprioritization and selective shelter. The first Secretary of Homeland Security, John Kelly, made this announcement just days after the inauguration: "Effective immediately... Department personnel shall faithfully execute the immigration laws of the United States against all removable aliens... [P] rosecutorial discretion shall not be exercised in a manner that exempts or excludes a specified class or category of aliens from enforcement of the immigration laws."

Since then, immigration officers have been arresting, charging and deporting the formerly tolerated: undocumented children, sick people, young mothers, military veterans, cooperating witnesses and others. ${ }^{6}$ Additionally, after months during which Trump personally professed assurances to, and sympathy for, DACA's beneficiaries, his administration announced rescission of the program. This means that 800,000 undocumented young people will likely lose their permission to remain and work and will soon become deportation priorities if Congress does not intervene. ${ }^{7}$ The administration has also announced that it will terminate temporary humanitarian protection programs for tens of thousands of Nicaraguans and Haitians.

Mandating that any person suspected to be out of status is an enforcement focus represents a huge widening of the enforcement net. In practical terms, it will almost always be people who "look Mexican" or "look Middle Eastern or Arab" who appear to be potentially out of status. ${ }^{8}$ Thus, not only has the pool of enforcement priorities been exponentially enlarged but it is a pervasively racialized enlargement.

\section{Heightened criminalization of immigration violations}

Together with the end of discretionary forbearance, we must note that immigration violations have been increasingly redefined as criminal violations in the U.S. (and elsewhere) over the past few years. ${ }^{9}$ Previously, basic immigration offenses (e.g., "entry without inspection"; "reentry after removal") had mostly been treated as civil offenses (though statutory law contained resources for criminalized enforcement). Earlier administrations had only minimally begun to criminalize the field as a matter of enforcement. But Trump's Attorney General Jeff Sessions has specifically instructed federal prosecutors to "increase [their] efforts...[in] making immigration offenses higher priorities" for criminal enforcement (Attorney General 2017). As stated by Sessions: "Under the President's leadership and through his Executive Orders, we will secure this border and bring the full weight of both the immigration courts and federal criminal enforcement to combat this attack on our national security and sovereignty." 10

\section{Expansions of the Domains of Immigration Enforcement}

Another of the Trump administration's significant innovations is the radical expansion of the domains and loci of immigration enforcement. Immigration and Customs Enforcement (ICE) - the internal immigration enforcement arm of the Department of Homeland Security - has launched a concerted campaign of 
investigations and arrests in venues that, under previous administrations, had been treated as "sensitive locations" - state-maintained domains that, I have argued, functioned as "sanctuaries" of sorts - and were thereby off-limits as a matter of discretion. Yet in the new moment, ICE agents have all-but abandoned the policy, and arenas once relatively insulated are now fair game. ${ }^{11}$ Significant enforcement efforts have thus been launched in local courthouses, where individuals are engaged in proceedings over child custody, domestic violence and landlord/tenant disputes. ${ }^{12}$ ICE officers have also arrested people in hospitals and clinics, in school drop-off zones, in public libraries and neighborhood centers, in food pantries and grocery stores, as well as in homes and workplaces.

Meanwhile, the Trump administration has mandated detention for virtually all noncitizens while in immigration proceedings. To house them all, it is reverting to reliance on private detention companies - a practice Obama had ordered discontinued at the end of his term. (Indeed, the stock of the former Corrections Corporation of America, recently self-rebranded as CoreCivic, more than doubled immediately after the election. See Long 2017).

\section{Expansion of Class of Enforcing Entities}

Finally, and significantly, the U.S. federal government has sought to expand the class of parties who enforce. States and localities are being enlisted, by both invitation and coercion, to partner with the federal government in enforcing immigration law. ${ }^{13}$ Some states and localities are eager to team up. Others are refusing to assist or even cooperate with the new enforcement surge, at least to a point, leading to various unfolding struggles often dubbed "sanctuary cities" policies. They justify their refusal in the name of public safety, arguing that when undocumented immigrants fear encounters with the police as crime victims or witnesses, communities suffer. The Trump administration, in turn, is seeking to force compliance by threatening withdrawal of federal funding. Whether such coercion is constitutionally permissible is being litigated in the courts (e.g., Gerstein 2018).

The Trump administration has also made efforts to promote "private immigration enforcement". The US government has had a "tip line" that private parties can call to report suspected undocumented immigrants, but it had long lain dormant. The line has been revived and publicly showcased, ${ }^{14}$ and its use is being encouraged by Trump's base. For example, celebrity fascist bad-boy Milo Yianopoulous reportedly urged the crowd at a 2017 speech at the University of New Mexico to "purge your local illegals" and gave out the report-line number (Hadfield 2017).

All of the foregoing developments amount to this: more immigration enforcement in more domains against more individuals at more times by more and more diverse agents. This is what I mean by internalized border pervasion. And while it remains true that persons who are territorially present are entitled to some protections in some domains against the force of the border law, it is also true that the insulated spaces of liberal individual protection are being drastically narrowed. Courts may push back to some degree. For example, if authorities were to enter a primary or secondary school to enforce immigration law, courts would likely enjoin because the U.S. Supreme Court held in a case called Plyler v. Doe that, as a matter of constitutional equal protection, undocumented children are entitled to access to 
education (although even here, the Trump administration is signaling a testing of limits. See Klein 2018). Nevertheless, the judiciary tends to understand its reviewing role in the immigration sphere as limited and properly deferring to the political branches. Without electoral reversals, the institutional constraints on increasing border pervasion will be limited.

\section{Resistance and "Sanctuary"}

These recent developments have taken us from what was already a grim situation for irregular immigrants in the United States to a real siege condition. Still, this enforcement deluge is not going unchallenged. Resistors of various stripes seek to block and oppose many of these initiatives in an effort to shield and protect immigrants and hold the government to account.

Much of the opposition is taking place in the legal domain, with challenges to the travel ban and to federal coercion of states and localities predominating. More opposition still is taking a political and civic form: lobbying, marching, letterwriting, fundraising and other acts of protest and solidarity - including DACA (DREAMER) activism especially, though so far, progress here has been minimal.

How might we think about the nature of this resistance? What is being opposed, and on what basis? One place to begin is with the concept of "sanctuary." Many have characterized the various strands of the resistance as part of a broader "politics of sanctuary". The term sanctuary, first of all, has become widespread in relation to so-called sanctuary cities, although many cities themselves are reluctant to use the term and prefer the more anodyne "welcoming cities". Additionally, houses of worship are re-embracing the provision of physical "sanctuary" to individual families. Meanwhile, some University campuses have declared themselves "sanctuaries' or have debated doing so. ${ }^{15}$ The idea of sanctuary has entered the curriculum: a group of progressive faculty and students recently published an extensive syllabus, titled "Sanctuary Syllabus" which "introduces readers to the intellectual and social histories that have given life to today's sanctuary movement" (NYU Sanctuary 2017).

What, we might ask, do these sanctuary-denominated initiatives have in common? To be clear, "sanctuary" is a term of art, not a technical term. In the U.S. context, it has become an umbrella concept covering a broad array of protective stances - some more affirmative, some more defensive; some publicly proclaimed, some unspoken. The idea is invoked to encompass a multiplicity of activities undertaken by an array of parties.

Nevertheless, I would maintain that these various instantiations of resistance contain a common normative thread. In all of its incarnations, sanctuary entails some commitment to cabin or abridge the jurisdictional scope of the border's operation. The sanctuary impulse endeavors to insulate certain domains and spaces and moments from the reach of the interior border, both practically and symbolically. Sanctuary both insists upon and evokes jurisdictional bulwarks, force fields and firewalls between the state's immigration enforcement authority and various domains of civil society in which precarious status immigrants conduct their lives. In this way, we might say that sanctuary stands against border totalitarianism. It demands that borders themselves be bounded. 
That being the case, how can we characterize what is ethically at stake in these various projects? What is the underlying political vision that sanctuary embodies, and what grounds the impulse that animates its insistence on border containment?

A cursory survey shows that sanctuary discourse and activism are structured around a variety of distinct normative logics, whether express or latent. One logic - perhaps the most prevalent - derives from natural law-based humanitarianism. Versions of such an understanding are implicit in the dictionary meaning of the term "sanctuary", which evokes a hallowed space of worship. Indeed, earlier movements of immigration sanctuary in the U.S. were directly religious and church led, and associated with a "welcome the stranger" faith-based biblical imperative. Increasingly secular versions of a humanitarian-motivated sanctuary are becoming more common as well, whether through emphasizing enlightenment norms of human dignity or an ethics hospitality, or both.

Notably, earlier recent sanctuary movements were centered on the persecuted refugees, asylees or fugitives from injustice (Emanuel 2014). Although this history certainly resonates, shielding people who have specifically fled persecution is not the central articulated goal of today's sanctuarists. Rather, the humanitarian imperative is more often expressed as a kind of community-based ethos of civil society, one in which organizations and individuals seek to protect their own consociates - neighbors, friends, colleagues, students, co-workers - from stateimposed harm. This protective discourse is frequently coupled with an assertion that the targets are already community members, that they are "Americans in all but name" - thereby appending to humanitarianism appeals the idea of a shared, non-legal status based, national civic identity.

In addition to this ethical version of sanctuary, one commonly hears a distinct strand as well - one explicitly invoking instrumental rationalities of community self-interest. This is the form of sanctuary discourse issuing from many cities and local police departments, which - as noted earlier - declare that non-cooperation with federal immigration authorities is essential to the protection of local communities. To successfully fight crime, per this argument, you have to maintain relations of trust between community, law enforcement personnel and local social service providers. And to do that, noncitizens cannot be afraid that the police or providers are working hand-in-hand with ICE. The position, in short, is that the internalized border must be constrained to ensure the well-being of the rest of us (de Lancer Julnes and Gibbs 2017). Here, the logics of localism are linked with community safety discourse. But they sometimes go beyond this as well, because localism involves invocations of principles of democratic self-rule, of states' rights, city autonomy and - per constitutional federalism principles - claims against national commandeering. And indeed, the juridical fight over sanctuary often takes this form; advocates invoke the principle of sanctuary to defend local power as against national power, and to cabin the scope of federal coercion of local action. Many sanctuary advocates find themselves enthusiastic state and local rights advocates on this issue (Kwong and Roy 2018).

These, then, are some of the discursive strands recently taken up by sanctuary politics in the United States: humanitarianism, democratic self-rule, pragmatic selfinterest. But beyond them, what else can we find? Specifically, I want to ask: Is sanctuary a politics of justice - and if so, how? There is no question that a great many people who currently support or participate in sanctuary efforts understand 
themselves to be engaged in justice-pursuing practices - justice for, and on behalf of, undocumented immigrants. But what is the conception of immigrant justice that animates them? Or, to pose the question inversely - and this is the question that motivates me particularly - what is the nature of the injustice these irregular immigrants are understood to experience that the new sanctuarists are standing against and seeking to redress?

Let us posit for now that the "sanctuary" moniker serves as a short-hand today for a broad array of immigrant justice activity and sentiment, and that it is an umbrella concept that carries forward the broad, diverse immigrant justice movement that had already been developing over the pre-Trump era in the U.S. The most publicly consequential part of that movement was DREAMER activism. In the middle and latter years of the Obama administration, young undocumented activists ${ }^{16}$ were publicly "coming out" and declaring themselves "Undocumented, Unafraid and Unapologetic". ${ }^{17}$ They did so to great political effect, because, although the DREAM Act failed as a legislative project, their activism began to transform popular consciousness and later ensured administrative passage of DACA. But that was then. Today, in light of the recent rampage of interior enforcement and now the rescission of DACA, the undocumented are structurally in less of a position to take a frontally unapologetic stance. They are necessarily more afraid, though the activism continues.

I would note that when the undocumented speak, they tend not to expressly invoke the notion of "sanctuary" as a political goal. This is likely because the term seems, on its face, to denote a condition of protection they must seek from others. Instead, undocumented activists have proclaimed that they are "\#HereToStay." This powerful slogan communicates a self-authorizing political demand - it performs a claim of right rather than a bid for mercy (The Guardian 2017). It is a declaration of entitlement - one that is de facto unapologetic - to continue to maintain physical presence and/or residence in the territory.

Nevertheless, it seems to me that today's proliferating invocations of sanctuary have come to incorporate this kind of claim. That is, beyond the logics of humanitarianism, localism and community self-interest, much of the post-Trump election sanctuary discourse is directly or implicitly taking up this "here-to-stay" message and carrying it forward. Claims of sanctuary - by scholars, by activists, by universities - are becoming more affirmatively, more trenchantly political, and are associated with a more demanding ethics of justice. Many young sanctuary activists - particularly on college and university campuses (most of whom are not undocumented themselves but allies) - are embracing Here-To-Stay politics, grounded in an ethics of territorial presence. This politics is in their literature; it is on their banners. Meanwhile, immigrant activists seem glad to ally themselves with the idea and politics of sanctuary, where sanctuary is understood to stand for more than compassionate protection.

Assuming the politics of sanctuary today has come to embody strands of a \#Here-To-Stay political ethics, now is the moment to inquire what such a political ethics entails. At its core, Here-To-Stay is anti-deportation politics. It is politics that demands "Not-One-More" expulsion. ${ }^{18}$ It is politics that regards forced removal or deportation as an injustice.

And how is deportation an injustice? The motivation for this claim is what I will call an ethics of presence (Bosniak, 2007). By an ethics of presence, I mean that the 
ethical basis for justice claims by and for undocumented immigrants is said to be the fact of their extant territorial presence, the fact that they are already here. The argument is that their already-hereness is something to defend: and an injustice would be committed if it were to be forcibly interrupted, and if persons were to be uprooted and expelled.

Now, in response I must first emphasize that defending the fact of extant presence as the basis for continuing presence is a highly radical politics, not merely now but also in less draconian political times. Liberals, political and theoretical, tend not to be found among the "Not-One-More," Here-To-Stay anti-deportation crowd. Indeed, liberal nationalists usually concede the legitimacy of deporting irregular immigrants in some circumstances, so long as it is undertaken with due process. They maintain that deportation becomes ethically unjustifiable only after an "otherwise-law-abiding" (non-criminally- convicted) person has lived in the country for some years (and/or when they were "not at fault" for their presence because they were brought by their parents as children or because they were fleeing persecution). As the liberal political theorist Joseph Carens put it when arguing on behalf of "amnesty" for some undocumented immigrants: "The longer the stay, the stronger the claim" (Carens 2013) ${ }^{19}$ The implicit corollary, of course, is: the shorter the stay, the weaker the claim (Bosniak 2015). Presence per se does not ground the claim.

By contrast to the mainstream liberal posture, a Here-to-Stay politics does not treat membership only as earned with time and good behavior (although even in this discourse, the length-of-time- present is sometimes treated as implicitly strengthening the claim). Nor does an anti-deportation politics accept the implied concession embedded in standard legalization discourse that irregular immigrants must be forgiven an earlier wrong - wrongful entry, wrongful visa violation - or that that the wrong must be forgotten via an official act of oblivion (Bosniak 2013). It is, in this respect, a non-repentant politics. Immigrants are Here-To-Stay because, when it comes down to it - and to paraphrase another key immigrant justice slogan - "No-one (Here) is Illegal." As such, it is an extremely demanding claim, one that rejects a defensive, feasibilist discursive universe (Bosniak 2016).

In short, Here-To-Stay-motivated sanctuary politics is radical relative both to most standard liberal stances on irregular migration and to apolitical humanitarianism (Ticktin 2015). It is a claim for justice, not simply shelter or forgiveness, a demand for and by subordinated and marginalized persons to retain what is theirs by right.

Yet, that said, I would also suggest that in some respects, Here-To-Stayism and the attendant newer versions of Sanctuary embody an ethically limited political imaginary. Most fundamentally, the scope of the justice claim remains both territorially and nationally endogenous. It grounds itself in the fact of these persons' extant presence inside the territory rather than being outside it. Additionally, it is temporally presentist, with its focus the fact of being here now. In brief, Here-toStay is a claim that invokes a person's already-achieved territorial presence still held in the current moment as something to defend.

While far more rigorous than standard arguments for legalization or amnesty based on an eventual "supersession of the wrong over time," a political ethics based on the fact of hereness-now nevertheless sidelines fundamental analytical issues that are key for critical normative political theory. Most significantly, such an ethics 
elides the reality that gaining access to hereness in the first instance is itself policed and restricted. Hereness is a scarce commodity, limited in its acquisition by force as well as circumstance. Nor does a \#Here-To-Stay ethics quite address the reality that the internalized operation of these same border restrictions functions to produce the illegalized status that, in turn, triggers the deportation machinery which seeks to oust certain persons from territory in the first place.

My point is that there is something both incomplete and incoherent about focusing only on the right-to-stay side of things without critiquing the initial constraints on getting to the place one demands to stay in; without, that is, interrogating a regime that uses force to impede access to territory and imposes illegalized status on those who do access it. An anti-deportation position alone doesn't address those who were stopped from being here, nor does it speak for those who were once here and departed, either on their own or via deportation (unless a politics of presence becomes not just a politics of being-here-now but a politics of "once having been here"), nor does it speak for those who never came or never tried to come. Finally, a here-to-stay, anti-deportation politics lacks the ballast on its own to challenge the subordinated status experienced by territorially-present noncitizens, even if they were to be shielded from physical expulsion proper. An anti-deportation stance, without more, could be consistent with noncitizens remaining in some sort of precarious status (under mechanisms like DACA or TPS in the U.S. - to the extent these remain available at all under the Trump-Sessions regime).

For this reason, I would suggest that, for theoretical purposes, we open up the conversation about immigration justice to include two more satisfying critical approaches. One of these would link immigrants' current territorial presence to specific geopolitical and economic histories. From this perspective, coming here in the first instance has to be understood as the product or sequelae of past forms of domination, economic or political, by the destination state or elements thereof. In this narrative, "Here-to-Stay" becomes not a claim about the significance of beinghere proper, but one mode among others to redress or correct forms of historical injustice on the part of colonial states (actual or functional, Bosniak 2016). This redress would include the right of those affected and their descendants to enter and be incorporated into the former colonial nation.

A second approach would be a wholesale "No Borders"/border abolitionist position. "No Borders" - or border abolitionism - embodies a different strand of radical immigration politics, a strand that has flourished more often in Europe and Canada. This is a politics that stands for freedom of movement across a more justly organized planet Earth. It is an anti-nationalist, possibly anarcho-libertarian stance that has a long international history - though it has less uptake in the U.S. where I have argued - a territorial-nationalist Here-To-Stay politics recently predominates.

Both corrective justice and No-Borders approaches are, in principle, more satisfying and more critically trenchant than "Here-to-Stayism," precisely because their gaze is less spatially and temporally insular. They have the potential to critically scrutinize the global migration system - and the set of relations of political and economic domination in which it is embedded - more broadly.

Here, though, is where we return to the earlier discussion of current immigration resistance. If more trenchant forms of border abolitionism were to become salient, 
where would that leave claims of "sanctuary"? Would the idea of sanctuary have the capacity to follow?

I should note that some voices in activist circles seek to harness the justice-linked undercurrent of the sanctuary term more radically and broadly to extend beyond the immigration setting altogether. ${ }^{20}$ On this view, sanctuary can "tackle not just immigration-related... policy but also policies related to issues like law enforcement, education, labor, gender, and economic justice," thereby "bringing more people under [sanctuary's] dome" (Farman 2017). These invocations of "extended sanctuary" are intriguing and provocative, though they require further elaboration and theorization. ${ }^{21}$ One might wonder whether deploying sanctuary in this "extended" sense would not diminish the concept's political potency as a term that today is understood to specify opposition to migrant-targeted oppression. On the other hand, rhetorically extending the concept could also enlarge migrantfocused political imaginations by linking various other struggles for social justice with those of immigrants. That would seem appropriate, since sanctuary's historical lineages both precede and exceed the migration setting (e.g., Smart 2013; Krauthamer 2017).

Putting aside deployments of the sanctuary term beyond the immigration setting, I want to conclude by venturing a few observations about how the concept of sanctuary offers both opportunities and constraints for theorizing immigration justice. Let's begin by noting that the generic meaning of "sanctuary" denotes the insulation of spaces and places and persons ("a place of refuge or protection," per the Merriam Webster English Dictionary). It thus designates shelter or immunity from some force or authority. In this respect, sanctuary is best regarded not as challenging state power frontally but as shielding against incursions of power. It is protective and defensive. Indeed, at its core, sanctuary embodies a politics of boundary maintenance. Notice what this means: The political valence of a sanctuary claim will depend in any given case on who is being shielded, against what or whom and by what means. It is not a necessarily an emancipatory politics, though it can be.

As a politics of boundary maintenance, sanctuary is in some respects quintessentially liberal in impulse. Liberalism stands for a politics of jurisdictional boundary maintenance; it demands the separation of spheres and powers. In political theorist Michael Walzer's terms, liberalism is "the art of separation" (Walzer 1984). ${ }^{22}$ And as it happens, in liberal democratic states like the United States, the jurisdictional sphere separation achieved via liberal legalism has been enormously protective for noncitizen immigrants. That this is so becomes particularly clear in moments like the present one, in which the authoritarianizing national state is smashing through prior jurisdictional boundary settlements and extending the interior border to reach an ever wider set of previously insulated spaces and moments and subjects. Which is to say: the aggressive processes of border pervasion unleashed by the Trump administration represent a systematic attack upon, and partial dismantling of, certain sanctuarist elements endemic to liberal legalism.

On the other hand, sanctuary politics can be deployed against liberalism as well as by it. As we have seen, deportation of noncitizens from the interior of a national state is a form of governance that most liberals have accepted in principle. A demanding sanctuarist politics can radically challenge this acceptance. Sanctuary 
in Here-ToStay incarnation embodies a demand by, and on behalf of, the territorially present for insulation against the force of the ejecting border. Sanctuary represents a demand to shield and protect people from state invasion of their already-hereness.

To this extent, immigration sanctuary converges in some respects with that strand of protectionist anti-slavery activism which shielded free or escaped persons against physical removal to slavery. It provides a logic of safe harbor. This is a valiant and radical stance.

But it strikes me that, in most conceivable political landscapes, advocates of immigration sanctuary are likely to stop short of demanding the equivalent of abolition of the slave system altogether. Fighting for the idea of border abolitionism - invoking the ethos of No Borders - requires a figurative sword, not only the shield that sanctuary embodies. It is true that sanctuary's critics caricature the project as committed to an anti-borders or open borders stance, but this is not quite accurate. Sanctuary's animating impulse is to protect from border power, not to deconstruct or destroy it. Sanctuary, it seems to me, stands fundamentally for the emborderment of borders. In the current moment, at least, this is a vital, and yet still utopian, project.

\section{Notes}

${ }^{1}$ Note also that international law imposes responsibilities on all sovereign states, liberal or otherwise, for treatment of territorially present noncitizens (i.e., citizens of other states). This is not merely a function of individual human rights obligations arising post WW II but, more longstandingly, of a legal regime grounded in states' responsibilities to other states - including the "host" state's responsibility to the state of which the territorially present noncitizen is a national. See generally Spiro (2011).

${ }^{2}$ Occasionally, claims are made on behalf of those already deported and thus no longer present - on grounds that their prior presence was wrongfully taken from them via wrongful deportation. These people seek restoration of that presence. See Bosniak (2016).

${ }^{3}$ This is a structure which Trump long claimed Mexico would pay for - and now the government claims it will be financed by a tax on remittances by Mexican immigrants to their country.

${ }^{4}$ Addition of Venezuela and North Korea to the list of precluded states was invoked to bolster administration's argument that it is not specifically anti-Muslim animus motivating the policy.

${ }^{5}$ Concept of "nativism" itself is both contested and internally complex. See Bosniak (1997).

${ }^{6}$ Meanwhile, the government has been engaged in a massive hiring campaign for ICE employees: the only area of federal government that is not being cut back. Recruiting is happening all over, including on college campuses.

${ }^{7}$ And even before their permits expire, scores of DACA holders have been targeted for deportation in the wake of minor traffic violations and status technicalities.

${ }^{8}$ Studies/litigation making point.

${ }^{9}$ And here, I must note that the statutory infrastructure permits this: the underlying statute delegating enforcement power to the executive branch offers the new 
administration plenty of room to proceed. That is: Much of what Trump is doing is entirely consistent with the statute.

${ }^{10}$ Moreover, per AG Sessions: "For those that continue to seek improper and illegal entry into this country, be forewarned: This is a new era. This is the Trump era. The lawlessness, the abdication of the duty to enforce our immigration laws and the catch and release practices of old are over." (Attorney General 2017).

${ }^{11}$ The ICE website states that it maintains a "sensitive locations" policy, though in narrowed form. In practice, the policy is often breached. Thus far, however, immigration enforcement actions have not been carried out in places of religious worship.

12 E.g., "ICE Formalizes Plans For Courthouse Arrests" http://www.chicago tribune.com/news/nationworld/politics/ct-ice-plans-courthouse-arrests-20180131 -story.html

${ }^{13}$ Sec. 287(g); mandates and "sanctuary cities"; tip lines.

${ }^{14}$ Homeland Security Investigations Tip Line: 866-DHS-2-ICE https://www.ice. gov/tipline

${ }^{15}$ Some universities embrace protective stances but have been unwilling to deploy the sanctuary term, either because they regard it as politically inflammatory or because they say it misleadingly suggests provision of greater protection to the undocumented than actually on offer. For general discussion of politicization of the sanctuary term, see e.g., Farman (2017).

${ }^{16}$ Referring to the DREAM Act, a legislative initiative that would have regularized hundreds of thousands of undocumented youth. Congress came close to passing that legislation more than once, and the Obama administration supported it, but it ultimately failed. It was in response to that failure that Obama implemented DACA.

${ }^{17}$ Bosniak, "Unapologetic" (2016). (Institute For Advanced Study) (unpublished paper).

18 "Not One More" is a slogan the immigrant justice movement has been pressing for several years.

${ }^{19}$ For further development of this argument, see Bosniak (2013).

${ }^{20}$ As one commentator put it, "black people need sanctuary cities too." (Bonsu 2017).

${ }^{21}$ New School for Social Research Initiative on Extended Sanctuary 2017-2018 (Ticktin, Farman Delano, McNevin).

22 "Liberalism is a world of walls, and each one creates a new liberty."

\section{References}

Armenta, A. (2017). Racializing Crimmigration. Sociology of Race and Ethnicity 3(1): 82-95. https://doi.org/10.1177/2332649216648714

Attorney General U.S. Department of Justice (2017, April 11). Memorandum For All Federal Prosecutors (press release). Renewed Commitment To Criminal Immigration Enforcement. Retrieved February 29, 2020, from https://www.justice.gov/opa/press-release/file/956841/download

Bonsu, J. (2017, March 10). Black People Need Sanctuary Cities Too. Essence. Retrieved February 23, 2020, from https://www.essence.com/news/politics/ sanctuary-cities-black-families-immigrants/ 
Border Security and Immigration Enforcement Improvements (Executive Order 13767), United States President, January 25, 2017. Retrieved February 29, 2020, from https://www.whitehouse.gov/presidential-actions/executiveorder-border-security-immigration-enforcement-improvements/

Bosniak, L. (1997). Nativism: The Concept. In Perea, J. F. (ed.), Immigrants Out! The New Nativism and the Anti-Immigrant Impulse in the United States (pp. 279-299). New York: NYU Press.

Bosniak, L. (2006). The Citizen and the Alien. Dilemmas of Contemporary Membership. Princeton, Princeton University Press. https://doi.org/10.1515/ 9781400827510

Bosniak, L. (2007). Being Here: Ethical Territoriality and the Rights of Immigrants. Theoretical Inquiries in Law 8(2): 389-410. https://doi.org/10.2202/15653404.1155

Bosniak, L. (2010). Persons and Citizens in Constitutional Thought. International Journal of Constitutional Law 8(1): 9-29. https://doi.org/10.1093/icon/ mop031

Bosniak, L. (2013). Amnesty In Immigration: Forgiving, Forgetting, Freedom. Critical Review of International Social and Political Philosophy (CRISPP) 16(3): 344-365. https://doi.org/10.1080/13698230.2013.795705

Bosniak, L. (2015). Review of J. Carens, The Ethics of Immigration. Ethics 125(2): 571-576. https://doi.org/10.1086/678367

Bosniak, L. (2016). Wrongs, Rights and Regularization. Moral Philosophy and Politics 3(2): 187-222. https://doi.org/10.1515/mopp-2016-0036

Bosniak, L. (2017). Varieties of Noncitizenship. In Baubock, R., Bloemgrad, I., Shachar, A., Vink, M. (eds.), Oxford Handbook of Citizenship Studies (pp. 314-336). Oxford: Oxford University Press.

Carens, J. (2013). The Ethics of Immigration. Oxford, Oxford University Press.

Darren Price, R. (2017, December 11). President Trump on Port Authority Bombing: 'End Chain Migration'. NBC. Retrieved February 23, 2020, from https://www.nbcdfw.com/news/politics/President-Trump-Chain-MigrationPort-Authority-Bus-Terminal-Bombing-Explosion-463482233.html

Dawsey, J. (2018, January 12). Trump derides protections for immigrants from 'shithole' countries. Washington Post. Retrieved February 29, 2020, from https://www.washingtonpost.com/gdpr-consent/?next_url=https\%3a\%2f\%2f www.washingtonpost.com $\% 2$ fpolitics $\% 2$ ftrump-attacks-protections-forimmigrants-from-shithole-countries-in-oval-office-meeting $\% 2 \mathrm{f} 2018 \% 2 \mathrm{f} 01 \%$ 2f11\%2fbfc0725c-f711-11e7-91af-31ac729add94_story.html

de Lancer Julnes, P. and Gibbs, J. C. (2017, April 25). Does cooperating with ICE harm local police? What the research says. Retrieved February 23, 2020, from https://theconversation.com/does-cooperating-with-ice-harm-local-policewhat-the-research-says-76072

Emanuel, G. (2014, March 27). Religious Communities Continue The Long Tradition Of Offering Sanctuary. Npg. Retrieved February 23, 2020, from https://www.npr.org/2017/03/14/519307698/religious-communitiescontinue-the-long-tradition-of-offering-sanctuary? $t=1582556238638$

Farman, A. (2017, April 6). In Defense of Sanctuary. The Baffler. Retrieved February 23, 2020, from https://thebaffler.com/latest/in-defense-of-sanctuary-farman 
Gerstein, J. (2018, January 24). Justice threatens subpoenas in sanctuary cities funding fight. Retrieved February 23, 2020, from https://www.politico.com/story/2018/01/24/sanctuary-cities-justicedepartment-subpoenas-365465

Hadfield, J. (2017, January 28). Milo Gives ICE Hotline To UNM Students. Breitbart. Retrieved February 23, 2020, from http://www.breitbart.com/ milo/2017/01/28/milo-unm-heres-ices-phone-number-use-wisely

Klein, R., (2018, May 23). Betsy DeVos Stirs Uproar By Saying Schools Can Call ICE On Undocumented Kids. Huffington Post. Retrieved February 23, 2020, from https://www.huffingtonpost.com/entry/betsy-devos-uproar-schoolscall-ice-undocumented-kids_us_5b05a297e4b05f0fc8441ce3

Krauthamer, B. (2017, February 27). Sanctuary Cities Have Historical Roots in Slavery-Era U.S. Portside. Retrieved February 23, 2020 https://portside.org/2017-02-27/sanctuary-cities-have-historical-rootsslavery-era-us

Kwon, C. and Roy, M. (2018, January 20). Local Action, National Impact: Standing Up for Sanctuary Cities. Yale Law Journal Forum. Retrieved February 23, 2020, from https://www.yalelawjournal.org/forum/local-action-nationalimpact

Long, H. (2017, February 24). Private prison stocks up 100\% since Trump's win. Cnn. Retrieved February 23, 2020, from http://money.cnn.com/ 2017/02/24/investing/private-prison-stocks-soar-trump/index.html

NYU Sanctuary (2017, May 12). Sanctuary syllabus. Retrieved February 23, 2020, from http://www.publicbooks.org/sanctuary-syllabus/

Smart, A. (2013). Sanctuary and Crime in the Middle Ages 400-1500. The Journal of Legal History 34(1): 117-120. https://doi.org/10.1080/01440365.2013. 771842

Spiro, P. J. (2011). A New International Law of Citizenship. The American Journal of International Law 105(4): 694-746. https://doi.org/10.5305/amerjintelaw. 105.4.0694

The Guardian (2017, December 14). We're here to stay: dreamers take over Guardian US. The Guardian. Retrieved February 23, 2020, from https://www.theguardian.com/us-news/series/were-here-to-stay/2017/dec/ $14 /$ all

Ticktin, M. (2015, September 18). The Problem With Humanitarian Borders, Toward A New Framework of Justice. Public Seminar. Retrieved February 23, 2020, from https://publicseminar.org/2015/09/the-problem-withhumanitarian-borders/

Volpp, L. (2002). The Citizen and the Terrorist. UCLA Law Review 49: 1575-1600. Retrieved February 23, 2020, from https://papers.ssrn.com/sol3/ papers.cfm?abstract_id=313859

Walzer, M. (1984). Liberalism and the Art of Separation. Political Theory 12(3): 315-330. https://doi.org/10.1177/0090591784012003001

Weston Phippin, J. (2016, April 29). Australia's Controversial Migration Policy The Atlantic. Retrieved February 23, 2020, from https://www.theatlantic.com/ international/archive/2016/04/australia-immigration/480189/ 